Kruger, JP

Fakulteit Teologie,

Noordwes-Universiteit

\title{
Sakramentele kerkwees herontdek
}

\section{ABSTRACT \\ Rediscovering a sacramental ecclesiology}

The demise of a participatory world view - characterized in this article as a world view of transcendence in immanence - has had far reaching consequences for the understanding of the church, the embodiment par excellence of transcendence in immanence. This article traces the radical separation of transcendence and immanence with special reference to the influence it has had on ecclesiological understanding by contrasting it with the sacramental, participatory world view of the first millennium of the church's existence. The central claim of the article is that the rediscovery and subsequent recovery of a truly sacramental understanding of the church is of vital importance to the current context, characterized as it is by schisms and seemingly irreconcilable antagonisms. Such a recovery would not entail an impossible return to premodern times, but would encompass the inflected, interpretive performance of salient themes from the time prior to the advent of modernity.

\section{INLEIDING}

Die oorgang vanaf die laat Middeleeue na die moderne tyd kan terugskouend verstaan word as 'n oorgang wat met ' $n$ epogmakende filosofies-teologiese ontwikkeling gepaardgaand gegaan het, te wete die radikale en absolute skeiding van transendensie en immanensie. Die disintegrasie van'n wêreldbeeld van transendensie in immanensie in'n proses van sekularisasie wat steeds aan die gang is, het verreikende gevolge gehad vir die verstaan van die kerk, die beliggaming par excellence van transendensie in immanensie.

In hierdie artikel word die kontoere van 'n deelnemende wêreldbeeld, 'n wêreldbeeld van transendensie in immanensie, eerstens in breë trekke geskets. Vervolgens kom die verval van die deelnemende wêreldbeeld in die radikale skeiding van transendensie en immanensie aan die orde, met spesifieke verwysing na die implikasies daarvan vir die siening van die kerk en van die verstaan van kerkwees.

Die artikel sluit af met die voorstel dat die herontdekking van 'n waarlik sakramentele verstaan van kerkwees dringend noodsaaklik is vir die konteks waarin die kerk homself tans bevind, en maak ook sekere voorstelle vir ' $n$ praktiese begin met so 'n herwinningspoging. Die herontdekking en herwinning van'n deelnemende wêreldbeeld sal natuurlik nie kan beteken dat sodanige wêreldbeeld eenvoudig na vandag oorgeplaas word nie. Waarvoor die skrywer wel pleit, is dat sekere temas vanuit die tradisie voor die aanvang van die moderne tyd op 'n toegeëiende en geïnterpreteerde wyse vir vandag gedramatiseer word. ${ }^{1}$

1. Nadenke oor hoe so 'n dramatiese herinterpretasie op 'n metodologies regverdigbare wyse kan geskied, kan aansluiting vind by die gedagte van 'n "inflected interpretive performance", soos voorgestaan deur Rowan Williams. Vgl. McCurry, J. 2007. "Towards a poetics of theological creativity: Rowan Williams 
NGTT: Oopbron - http://ngtt.journals.ac.za

\section{Kontoere VAn 'N DEELNEMENDE WÊRELDBEELD}

Die wêreldbeeld wat vir die eerste duisend jaar van die kerk se geskiedenis deel van sy selfverstaan uitgemaak het, kan in ' $n$ belangrike opsig as' $n$ deelnemende wêreldbeeld beskryf word. ${ }^{2}$ Hiervolgens moet die bestaan (die wese, die syn) van die ganse skepping verstaan word as dat dit deelneem in die bestaan (die wese, die syn) van God. Hoewel die skepping natuurlik nie self God is nie (dit is juis 'n skepping wat God ex nihilo laat wees het), is dit ook nogtans nie los te verstaan van God nie. Wat goed is in die skepping, is goed omdat, en tot die mate waarin dit deel in God, die hoogste Goed. Wat waar is in die skepping, is waar omdat en tot die mate waarin dit deel in God, die Waarheid self. Dieselfde geld vir wat mooi is in die skepping. Dit geld verder nie slegs vir die attribute van die skepping nie, maar inderwaarheid vir die bestaan van alle eindige dinge.

Die kontoere van ' $n$ deelnemende, teologiese wêreldbeeld het beslag gekry in die eerste eeue van die Christelike jaartelling soos wat die kerkvaders, in gesprek met die Hellenistiese filosofieë en godsdienstige dwaalleringe, genoodsaak was om die verhouding tussen God en die skepping noukeurig te verwoord. In die hitte van die trinitariese en Christologiese kontroversies het die kerkvaders van die noukeurige onderskeidings gebruik gemaak wat eie was aan die Griekse filosofiese denkwêreld waarin baie van hulle ook, vanuit hulle opvoeding tuis was. Derhalwe, in die vierde eeuse Kappadosië het kerkvaders soos Basileus die Grote en Gregorius van Nyssa ter verdediging van die ortodoksie van die Konsilie van Nicéa, aangevoer dat die Christelike God enersyds oneindig meer transendent is aan die skepping, maar andersyds ook juis oneindig nader is aan die skepping as wat die metafisika van die Griekse filosofie kon akkommodeer. In die woorde van David Bentley-Hart:

"In the fourth century the Cappadocians, in their struggle against the pneumatomachoi, made it clear that the elaborate, but explanatory metaphysical hierarchies of Alexandrian speculation ... were alien to genuine Christian trinitarianism, and that the Christian God is at once infinitely more transcendent of and, in consequence, infinitely nearer to (within the very being of) finite reality than was the inaccessible God of antique metaphysics ..."3

Dieselfde konsensus as wat deur die Kappadosiese vaders in die Ooste gehuldig is, is ' $\mathrm{n}$ eeu of wat later deur Augustinus in die Weste voorgestaan. Volgens hom is God enersyds interior intimo meo ("nader aan my as wat ek aan myself is"), terwyl dit terselfdertyd ook so is dat God superior summo meo is ("hoër as die hoogste waarby ek kan kom.") God is inderdaad altyd groter. $^{4}$

' $n$ Deelnemende wêreldbeeld is ' $n$ wêreldbeeld waarin die immanente (die skepping) nie

reads Augustine's De Doctrina after Derrida” In: Modern Theology, 23 (3), July.

2. In hierdie verband kan gekyk word na die nou reeds klassieke studie van Henri de Lubac wat in die veertigerjare van die twintigste eeu in Frans gepubliseer is: De Lubac, H. Corpus Mysticum - The Eucharist and the Church in the Middle Ages, vert. Simmonds, G (Notre Dame, Ind.: Univ of Notre Dame Press, 2006). Teen die einde van die twintigste eeu het Louis Dupré die oorgang vanaf die deelnemende wêreldbeeld na die moderne tyd in 'n invloedryke werk beskryf: Dupré, L. Passage to Modernity (New Haven: Yale University Press, 1993). Vanuit reformatoriese kringe is dieselfde genealogiese trajek onlangs deur Hans Boersema uitgemerk: Boersema, H. Heavenly Participation - the weaving of a sacramental tapestry (Grand Rapids: Eerdmans, 2011).

3. David Bentley Hart. The Beauty of the Infinite (Grand Rapids: Eerdmans, 2003) p. 182.

4. Confessiones, 3.6.11 "tu autem eras interior intimo meo et superior summo meo". Die uitdrukking "God is altyd groter" (Deus semper maior), is afkomstig uit die Enarratio in Psalmum LXII, 16: CCL 39, 804. 
absoluut geskei is van die transendente (God) nie, maar juis daarin deel het. In filosofiese taal uitgedruk, dui 'n deelnemende wêreldbeeld op 'n wêreld van transendensie in immanensie. In die taal van die Christelike teologie: die skepping bestaan as ' $n$ uitdrukking van die Woord van God. Dit is geskep deur die Woord (die tweede persoon van die goddelike Drie-eenheid), en as sodanig dra dit die karakter van die Logos. Nogtans beteken hierdie verstaan geensins dat die skepping self God is nie. Daar is juis die absolute noodsaak om 'n onderskeid te maak tussen die transendente en die immanente. In'n leerstelling van die vierde Lateraanse konsilie van 1215 word hierdie formulering van transendensie in immanensie op 'n klassieke wyse saamgevat: "'n Mens kan nie 'n ooreenkoms tussen die Skepper en die skepsel opmerk - hoe groot ook al - sonder om 'n nog groter verskil tussen hulle op te merk nie." Tot hoe'n mate daar ook al op grond van die deelnemende wese van die skepping 'n ooreenkoms tussen God en die skepping aanvaar word, moet dit altyd bevestig word teen die agtergrond van 'n groter, onkwantifiseerbare verskil.

Dat die wêreld verstaan is as deelnemend in die wese van God het beteken dat daar ruimte was daarvoor om die misterie waar te neem en te waardeer. Gewone aardse dinge is meer as wat dit op die oog af lyk. Die dinge van die geskape bedeling het hulle eie integriteit, en tog is daar ook altyd meer. ${ }^{6}$ Dit het gegeld vir die verstaan van siklusse in die natuur, van menselewens, van die plek van tegnologie, van instellings soos die koningskap, en, natuurlik, het dit heel in die besonder ook gegeld van die kerk. So was die kerk in sy totale bestaan 'n liturgiese viering en verdigting van die kontingente, deelnemende en ekstatiese gemeenskap wat die hele skepping was (of beter, veronderstel was om te wees, en nou weer in Christus waarlik kon wees.) Die kerk is'n hemelse gemeenskap in hierdie aardse gemenebes. In die lig van die kruis en die opstanding word Jesus Christus verstaan as die hoof van sy liggaam, die kerk. Die hoof is aan die regterhand van die Vader, en tog is die hoof nie ver weg van die liggaam asof die hemel 'n gelokaliseerde ander plek is nie. ${ }^{7}$ Die liggaam kan alleenlik ware liggaam wees tot die mate waarin dit deel in die hoof. Hierdie is die sakramentele logika waarop in die laaste deel van die artikel teruggekom word.

Die teologies-filosofiese wêreldbeeld van transendensie in immanensie het 'n monumentale formulering gekry in die werk van die dertiende eeuse Dominikaanse teoloog, Thomas van Aquino. Die genialiteit van Aquinas het daarin gelê dat hy die filosofie van Aristoteles, waarvan 'n groot deel wat verlore was in die voorafgaande eeu, weer vir die Weste beskikbaar geword het, kon inkorporeer binne die raamwerk van 'n Christelik-Platonistiese wêreldbeeld. Volgens hierdie benadering het die natuur 'n mate van selfstandigheid, sodat dit met die menslike rede bestudeer kan word. Die natuur is nogtans nooit sonder God se genade nie - in die besonder soos wat dit in Christus gegee is - met die gevolg dat die ganse skepping verstaan moet word as ekstaties. In God se openbaring word aan ons gegee wat die bestemming is waarheen die skepping deur God se liefde en genade op pad is. Ons mense se kennis vanuit God se openbaring kroon en deurdring ons kennis wat opgedoen word deur middel van die relatief selfstandige werkinge van die rede (hierdie is ' $n$ verhouding van transendensie in immanensie.) Die natuur kan dus selfstandig bestudeer word (sê maar deur gebruik te maak van die kategorieë van Aristoteliese logika en metafisika), maar hierdie beredenerings kan,

5. Uit kanonieke stelling 2: "quia inter creatorem et creaturam non potest similitudo notari, quin inter eos maior sit dissimilitudo notanda." Vgl. Medieval Sourcebook: Twelfth Ecumenical Council: Lateran IV 1215. Verkry by http://www.fordham.edu/halsall/basis/lateran4.asp Ook Betz, J.R. 2006. "Beyond the Sublime: The Aesthetics of the Analogy of Being (part 2)," Modern Theology, 22:1, p. 13.

6. Vgl. Boersema, Heavenly Participation, Kindle uitgawe plekmerker 263.

7. Ibid. Kindle plekmerker 98. 
NGTT: Oopbron - http://ngtt.journals.ac.za

en moet geïnkorporeer word binne die groter raamwerk van die teologie, waar dit die rol speel van argumente daarvoor dat geloofskennis nie absurd is nie. ' $n$ Belangrike element van die Aristoteliese filosofie wat deur Aquinas ontwikkel is in diens van sy teologiese projek, is die konsep van analogie. ${ }^{9}$ Hiervolgens moet daar oor die skepping se verhouding met God gepraat word nie in eenduidige (univokale) taal nie, want dit sou beteken dat God en sy skepping bloot dieselfde soort syn het. Daar moet ook nie oor die verhouding gepraat word in absoluut meerduidige of dubbelsinnige (ekwivokale) taal nie. Dit sou beteken dat daar geen deelnemende verhouding tussen die skepping en God is nie. Die taal wat geskik is vir die beskrywing van die wyse waarop geskape dinge deel in die syn van God is die taal van analogie. $^{10}$

\section{Die abSolute skeiding van transendensie en IMmANENSIE}

Teen ongeveer die veertiende eeu het die wêreldbeeld wat hierbo beskryf is, in ' $n$ krisis beland. ${ }^{11}$ Hierdie krisis, wat momentum gegee het aan 'n proses van sekularisering waarvan die einde steeds vandag nie volkome bereik is nie, kan teruggevoer word na ontwikkelings binne die teologiese wêreld van die laat-Skolastiek. Op grond van die logiese beginsel van uitgeslote teenstrydigheid het Johannes Duns Scotus geargumenteer dat dieselfde eienskap nie gelyktydig van God bevestig en ontken kan word nie. ${ }^{12}$ Die gedagte van analogie, waardeur God se nabyheid (immanensie), sowel as transendensie ten opsigte van die skepping bevestig kon word, het skynbaar al hoe meer onhoudbaar geword. Twee ontwikkelings het hieruit voortgevloei. Aan die een kant is die verhouding tussen God en sy skepping toenemend óf in volledig univokale terme óf in volledig ekwivokale terme beskryf. Enersyds: God en die skepping deel dieselfde syn; God is slegs oneindige syn terwyl die skepping eindige syn is. Andersyds: God en die skepping is totaal en al verskillend van mekaar. Die syn van die skepping het nie inherent iets met die Goddelike syn te make nie. Aan die anderkant het daar'n ontwikkeling plaasgevind waarvolgens die menslike denke al hoe meer losgemaak is uit die weefsel van die skepping, en as't ware los van, en teenoor die res van die skepping gekonsepsualiseer is. Waar die "dinge" vroeër, vanweë die deelnemende wêreldbeeld, as "woorde" na die denke kon migreer en so eintlik ekstaties uitreik na God toe ${ }^{13}$, het die interaksie van die menslike siel en die wêreld buite die siel nou hopeloos problematies geraak. Algaande het die woorde van die

8. Vgl. Bv. Summa Theologia, I, Q.1, Art. 1, antw. op beswaar 2: "There is no reason why those things which may be learned from philosophical science, so far as they can be known by natural reason, may not also be taught us by another science so far as they fall within revelation."

9. Vgl. Ashworth, E.J. 1991. "Signification and Modes of Signifying in Thirteenth-Century Logic: A Preface to Aquinas on Analogy" In: Medieval Philosophy and Theology, vol. 1. Ook: Ashworth, E.J. 2004. Medieval Theories of Analogy. In: Stanford Encyclopedia of Philosophy. Edward N. Zalta (ed.). Verkry by: http://plato.stanford.edu/entries/analogy-medieval/

10. Hoewel die term analogia entis nie by Aquinas voorkom nie, is die gedagte wel aanwesig. Die gedagte van analogia entis is verder ontwikkel, en het byvoorbeeld in die twintigste eeu die hoeksteen uitgemaak van die filosofies-teologiese werk van Erich Przywara. Sien Thomas Joseph White, O.P. (red.) The Analogy of Being - Invention of the Antichrist or the Wisdom of God? (Grand Rapids: Eerdmans, 2011).

11. Behalwe vir die werke waarna hierbo in voetnoot 2 verwys is, sien die bespreking in Eric Alliez se werk, Capital Times, p 197 e.v. "1300: The Capture of Being.” Alliez, E.Capital Times - Tales from the Conquest of Time. vert. deur Georges van den Abbeele (Minneapolis: University of Minnesota Press, 1996.)

12. Pickstock, C. 2005. Duns Scotus: his historical and contemporary significance. Modern Theology. 21(4).

13. Roberto Pellerey, Thomas Aquinas: Natural semiotics and the epistemological process, In: Umberto Eco \& Costantino Marmo (reds.) On the Medieval Theory of Signs (Amsterdam: John Benjamins Publishing Company, 1989), pp.81-105. 
denke'n eie bestaan gekry. Hulle representeer nou die dinge daarbuite, en is tot daardie mate waar of vals.

Hierdie twee ontwikkelings het op mekaar ingespeel, met die gevolg dat die wêreldbeeld wat uitgaan van 'n deelnemende verhouding tussen God en die skepping vernietig is. ${ }^{14}$ God is baie ver weg van die skepping af. Die eindige geskape wêreld is totaal anders as God. Geleidelik, deur die loop van die Renaissance en veral in die opkoms van die modernisme, het die fokus van die menslike gees verskuif na die ondermaanse wêreld toe. Dit is wat ondersoek en verstaan moet word. God se werksaamheid kan alleen maar verstaan word as 'n soort van 'n onderbrekende woord van buite af. Die goddelike openbaring val as't ware soos 'n klip uit die lug, en moet gewoon aanvaar word omdat dit gesagvolle openbaring is, nie op grond van enige resonansie met die ingeskape goddelike waarheid van die dinge nie. Daarmee saam word die groot vraag die vraag na die verhouding tussen die mens se binnewêreld en die wêreld daarbuite, oftewel die vraag na die verhouding tussen kennis en syn. Aangesien die syn van die skepping op geen wyse meer aanvaar kan word as dat dit natuurlik na God smag nie, moet die vraag na kennis eerste beantwoord word, voordat die vraag na die syn beantwoord kan word. En so vind, met die moderne tyd, daardie ontwikkeling plaas wat as die epistemologiese wending beskryf kan word. Voordat hoegenaamd oor die werklikheid gepraat kan word, moet klarigheid gekry word oor ons kennis van die werklikheid.

Die filosofies-teologiese ontwikkelings wat hierbo beskryf is, het ingrypende gevolge vir die denke oor en lewe van die kerk gehad. In sy boek, Corpus Mysticum, toon Henri de Lubac aan hoe dat die uitdrukking "die mistieke liggaam van Christus" tot ongeveer die agtste eeu juis op waarlik mistieke wyse kon verwys na Christus se liggaam wat gebore is uit Maria, na die kerk as die liggaam van Christus, en na die sakrament van die eucharistie. ${ }^{15}$ Geleidelik het daar egter 'n duidelik waarneembare verskuiwing plaasgevind in die manier waarop die uitdrukking corpus mysticum gebruik is. Terwyl daar enersyds in al hoe meer "realistiese" terme oor die sakramentele liggaam van Christus gedink is - die brood en die wyn is "regtig" die liggaam en bloed van daardie liggaam wat uit die maagd gebore is - is daar al hoe meer na die kerk as die mistieke liggaam verwys, maar dan in 'n bloot metaforiese sin. Hierdie ontwikkelings in die ekklesiologie en sakramentele teologie het nuwe momentum gekry in die absolute skeiding tussen transendensie en immanensie wat met die verlies van ' $n$ deelnemende wêreldbeeld na vore getree het. Waar dit in 'n deelnemende wêreldbeeld, 'n wêreld van transendensie in immanensie, moontlik was om oor die brood en die wyn van die nagmaal as analogiese (waarlik sakramentele) tekens te dink $^{16}$, noop die ontologiese en kenteoretiese ontwikkelings waarna hierbo verwys is daartoe dat die brood en die wyn enersyds as blote tekens verstaan word (veral in sekere reformatoriese kringe), of andersyds dat die brood en die wyn op feitlik magiese wyse verander word sodat daar geen teken-karakter meer in steek nie, maar dit die werklik fisieke liggaam van Christus is (sekere strominge binne die Rooms-Katolieke teologie na die Konsilie van Trent. $)^{17}$

14. Vir ' $n$ resente bespreking van hierdie ontwikkeling, sien Brad S. Gregory se werk, The Unintended Reformation. Gregory, Brad S. The Unintended Reformation - How a Religious Revolution Secularized Society (Cambridge, Mass.: Harvard University Press, 2012) - veral hfst. 1 "Excluding God."

15. De Lubac, Corpus Mysticum, pp. 21-24.

16. Vgl Boersema, Heavenly Participation, Kindle plekmerker $270 \mathrm{ev.}$

17. Vgl. Simon Oliver, "The eucharist before nature and culture" In: Modern Theology 15:3, Julie 1999.

Ook Catherine Pickstock: "Truth and Language" In: John Milbank \& Catherine Pickstock, Truth in Aquinas, (London: Routledge, 2001) pp. 88-111. 
NGTT: Oopbron - http://ngtt.journals.ac.za

Wat die kerk betref lei die ontruiming van die transendente uit die immanente, gepaardgaande met die teenoor mekaarstelling van die denkende menslike subjek en 'n materiële, objektiewe wêreld "daarbuite", daartoe dat die institusionele, politiese en organisatoriese kante van kerkwees al hoe meer op die voorgrond tree, terwyl die "verhouding met God" al hoe meer 'n saak van die individuele innerlike lewe word. Die filosofies-teologiese ontwikkelinge wat hierdie verskuiwing moontlik gemaak het, het, wat vir lank as 'n positiewe spanning beleef is, op'n breuk laat afstuur: die verhouding tussen die pous en die keiser, oftewel die verhouding tussen kerk en staat.

De Lubac beskryf hoe dat die kerk al hoe meer sy karakter van transendensie in immanensie verloor het, en dienooreenkomstig al hoe meer toegetree het tot sekulêre politieke magstryde. Dit het ook gepaard gegaan met'n groterwordende juridisering van die kerk. ${ }^{18}$ Die reformatore reageer hierteen deur die sigbare, beliggaamde kant van kerkwees as't ware prys te gee ten gunste van'n onsigbare mistieke liggaam van Christus, waarvan elke plaaslike kerk 'n vergestalting is. ${ }^{19}$

Die absolute skeiding van transendensie en immanensie het ook verreikende gevolge gehad vir die wyse waarop oor die verhouding tussen plaaslike kerke gedink is. Waar die verhouding tussen plaaslike kerke binne 'n deelnemende wêreldbeeld veel minder problematies was (almal deel in die een liggaam van Christus, en deel daarom ook in mekaar) het hierdie verhouding in die moderne tyd hoogs problematies geword. Filosofies gesproke was dit veral die opkoms van die nominalisme wat die verhouding tussen plaaslike kerke geproblematiseer het. 'n Nominalistiese benadering aanvaar geen inherente band tussen entiteite nie; elke entiteit is ' $n$ partikuliere individu. Die enigste verband wat tussen dinge bestaan is wat deur die denke daaraan opgelê word (deur bv. die gebruik van soortname.) ${ }^{20}$ Ten opsigte van die invloed van die nominalisme op die eenheid van die kerk merk Boersema die volgende op:

"Nominalism subverted this medieval sense of unity, since the new philosophical approach was predicated on the notion that each person was, as it were, a self-subsistent entity, whose being was, in principle, unrelated to the being of other persons. In other words, nominalism was the seedbed for modern individualism. It is easy to see that it is much more difficult for a nominalist than for a realist to concern herself with ecclesiastical unity: fragmentation lies at the heart of a nominalist ontology"21

Die Reformasie reageer, aan die hand van die radikale skeiding tussen transendensie en immanensie, teen die institusioneel-organisatoriese magsmisbruike van die Katolieke Kerk van destyds. Die Reformasie reageer deur in die plek van een kerk waarin op sakramenteelanalogiese wyse bemiddel word tussen plaaslike parogieë en die kerk as geheel, te stel dat daar twee verskillende (ekwivokale) wyses is waarop die woord "kerk" gebruik word: as beskrywing van elke plaaslike gemeente, wat in sigself volledig kerk is, en as beskrywing van die universele kerk. Enersyds word bevestig dat die universele kerk die een liggaam van Christus is. Maar

18. De Lubac, pp 116, 117. Vergelyk in hierdie verband ook Brad S. Gregory, The unintended Reformation, hfst. 3 "Controlling the Churches"

19. De Lubac, pp 116 en 117. Gregory, p. 140.

20. Dit is duidelik dat die nominalisme van die Laat Skolastiek, soos bv. in die denke van Willem van Ockham, nou aansluit by die ontwikkelinge wat vroeër verduidelik is, waarvolgens die denke losgemaak is uit die deelnemende plek wat dit in die geskape syn gehad het, en as't ware teenoor die res van die natuur te staan gekom het.

21. Boersema, Heavenly Participation, Kindle plekmerker 1053. 
andersyds word ook bevestig dat elke plaaslike kerk' $n$ volkome manifestasie van die liggaam van Christus is. Eksegetiese gronde word vir hierdie skeiding aangevoer. ${ }^{22}$ Die implikasies van hierdie siening is egter beduidenswaardig. Aan die een kant word die universele liggaam van Christus vergeestelik; dit is onsigbaar. Aan die anderkant word die individuele plaaslike kerk volkome selfstandig, en word die verhouding tussen plaaslike kerke eintlik'n sekondêre saak. Van nou af rus die bewyslas as't ware by diegene wat wil aantoon dat plaaslike kerke iets met mekaar te doen moet hê.

Die uitdaging vir so 'n siening van kerkwees is die vraag hoe daar tussen die twee ekwivokale bevestigings ten opsigte van die begrip "kerk" bemiddel kan word? Hoe word daar in die moderne tyd tussen die eenheid van die kerk en die veelheid van plaaslike gemeentes bemiddel? Christus regeer sy kerk deur sy Woord en Gees. Maar onder die invloed van die modernisme word hierdie regering 'n onliggaamlike, virtuele en prosedurele regering. Dit kan ook in praktyk nie anders as om 'n soort kontraktuele verband tussen losstaande plaaslike kerke tot stand bring nie.

Sedert die tweede helfte van die twintigste eeu is die institusioneel-kontraktuele opvatting van kerkwees toenemend gekritiseer vanuit'n perspektief wat 'n meer dinamies-kommunikatiewe verstaan van die kerk voorstaan. Sedert die laaste dekades van die vorige eeu staan hierdie nuwe benadering bekend as 'n missionale verstaan van kerkwees. Die kritiese vraag aan die missionale opvatting van kerkwees het te make daarmee of die negatiewe gevolge van die absolute skeiding tussen transendensie en immanensie werklik deur hierdie benadering aangespreek word. Word die ekwivokale interpretasie van ekklesia, waardeur daar'n absolute skeiding gemaak word tussen die universele kerk en die plaaslike kerk, hierdeur aangespreek? Anders gestel, kontinueer hierdie opvatting nie maar steeds die nominalistiese ontologie waarmee ons gelaat is aan die begin van die moderne tyd nie? Elke plaaslike kerk is volwaardig kerk, en in stede van 'n kontraktuele verband word die verhouding tussen die plaaslike kerk nou meer in terme van'n pragmatiese netwerk gesien.

\section{Sakramentele KerkWees}

Die absolute skeiding van transendensie en immanensie in filosofies-teologiese sin het verreikende gevolge vir die eenheid en lewe van die kerk gehad. In die lig hiervan hou die herontdekking en herwinning, in een of ander vorm, van 'n deelnemende wêreldbeeld groot belofte in vir die ekklesiologie. Sodanige projek sou nie'n blote nostalgiese hunkering na die verlede behels nie, maar sou 'n interpretatiewe en kontekstualiserende vormgewing moet wees van belangrike temas uit die tradisie van die Christelike geloof en kultuur voor die

22. Sien bv. Van Genderen en Velema, Beknopte Gereformeerde Dogmatiek, pp. 616-622. Twee opmerkings kan oor hierdie benadering, wat tipies van 'n breër sentiment is, gemaak word. In die eerste plek word die Skrif hanteer op 'n wyse wat tipies is van 'n denkhouding wat spruit uit die epistemologiese wending waarvan hierbo sprake was. Die outonome denkende subjek word losgemaak uit die boesem van die kerk wat dit tradisioneel liturgies sou begelei na verstaan, en kom as't ware langs die kerk te staan, om die kerk "in die lig van die Skrif" te beoordeel en te plaas. Dit is 'n nominalistiese hermeneutiek. Die Skrif speel in die verband dan die rol van 'n objektiewe kenobjek wat deur die rede bestudeer kan word ten einde positiewe feite daaruit te abstraheer. Dat die interpretasie van die Skrif plaasvind binne en aan die hand van die tradisie wat die liggaam van Christus is, daarvan is daar nie sprake nie. Vgl. J. Todd Billings, The Word of God for the people of God - An Entryway to the Theological Interpretation of Scripture, (Grand Rapids: Eerdmans, 2010), Kindle plekmerker 52. In die tweede plek is daar in hierdie etiologie van die begrip "kerk" feitlik geen band meer met die sakrament van die nagmaal, soos wat vir die grootste deel van die kerk se geskiedenis die geval was nie. 
NGTT: Oopbron - http://ngtt.journals.ac.za

aanbreek van die moderne tyd..$^{23}$ Die belangrikste waaroor dit in hierdie verband sal moet gaan, is dat daar'n hernieude sensitiwiteit sal moet kom vir die aanwesigheid van God in ons mense se ervaringswêreld. Hierdie hernieude sensitiwiteit, wat tegelyk'n verwoestende kritiek op die hele epog van sekularisering sal behels, kan geen ander oorsprong as die kerk self hê nie. Hierdie sensitiwiteit sal dus eers in die kerk self herontdek moet word. In die woorde van De Lubac:

"The Church, the body of Christ, is a mystery and against the flat notion of it conceived in the Enlightenment and repeated by a few followers of liberal Protestantism, it should be maintained that a mystery is what continues to remain obscure, hidden and 'mystical', even once it has been described, signified and 'revealed".'24

Die lyn wat deurlopend in hierdie artikel die basis van argumentasie vorm, is dat die verstaan van kerkwees wat die aanleiding kan gee vir 'n hernieude vorm van 'n deelnemende wêreldbeeld, ten nouste gekoppel behoort te wees aan'n herontdekking van die sakramentele aard van die kerk. Daar moet met ander woorde'n herontdekking plaasvind van die innerlike band tussen die ekklesiologie en die sakramentele teologie. Weereens in die woorde van De Lubac:

"From the beginning of Christianity, the Eucharist had always been considered in relation to the Church. The 'communion of the body of Christ' of which St. Paul spoke to the faithful of Corinth (1 Cor 10:17-18) was their mysterious union with the community, by virtue of the sacrament: it was the mystery of the Body formed by all those who shared in the 'one Bread'. In the same way, from that time on the Church had never ceased to appear linked to the Eucharist." 25

Vir'n hernieude verstaan van hoe die kerk as't ware uit die sakrament van die nagmaal gebore word, is dit nodig dat die sakrament self met hernieude waardering omhels word binne die kringe van die Protestantse kerke en teologie. 'n Kernvraag in hierdie verband het te make met die aanwesigheid of afwesigheid van die liggaam van Christus in die nagmaal. Wat is die strekking van die woorde "Dit is my liggaam" wat geuiter word in die viering van die nagmaal? Dit is juis 'n skreiende uitdrukking van die absolute skeiding tussen transendensie en immanensie dat die aanwesigheid of afwesigheid van die liggaam van Christus in die nagmaal in absolute en wedersyds uitsluitende terme bedink word. Aan die een kant word die liggaam van Christus as totaal afwesig geag tydens die viering van die nagmaal. Die nagmaal word in mimetiese terme ${ }^{26}$ verstaan as ' $n$ teken van die gebeure van Christus se kruisiging twee duisend jaar gelede, as 'n teken van die bruilofsmaal van die Lam wat in die toekoms voorlê, en as 'n seël van die geestelike voeding met die liggaam van Christus deur die Heilige Gees, terwyl die liggaam van Christus self elders geag te wees - in die hemel by die Vader. Op 'n ekwivokale - dit is op'n totaal onverwante - wyse word die kerk dan ook as die liggaam van Christus geag wat tydens die viering van die nagmaal aanwesig is. Die uitdrukking "liggaam van Christus" word in bloot metaforiese sin van die kerk as gemeenskap van mense gebruik, terwyl daar geen inherente band bestaan tussen die liggaam van Christus wat "in die hemel" by die Vader is, en die kerk wat in ruimte en tyd lewe en die nagmaal vier nie. In die verbygaan kan opgemerk word dat die semiologie waarvolgens die betekenaar en die betekende radikaal van mekaar geskei is, maar die betekenaar die betekende tog op 'n wyse representeer in die

23. Vgl. voetnota 1.

24. Corpus Mysticum, p. 251.

25. Ibid. p. 248.

26. Oliver, The eucharist before nature and culture, p. 343 
afgelope halfeeu uitvoerig gekritiseer is, ondermeer in die filosofie van Jacques Derrida.

Die teenoorgestelde beweging het egter ook in die glystroom van die absolute skeiding van transendensie en immanensie gebeur wat die opvatting van die nagmaal betref. Die tekenkarakter van die nagmaal, wat eie is aan die aard daarvan as sakrament of misterie, is ontken ten gunste van die bevestiging van die absolute aanwesigheid van die liggaam van Christus in die brood en wyn van die nagmaalviering. Die brood en die wyn is eintlik totaal vreemd en toevallig aan dit wat die eintlike liggaam van Christus is. In die woorde van Catherine Pickstock:

"The Eucharistic signs perforce become ... the site of an extrincisist miracle which stresses the alienness of bread from Body, and wine from Blood."27

In teenstelling hiermee is dit kardinaal dat die tekenkarakter van die nagmaal nie vanuit vreemde, moderne of postmoderne opvattings van 'n teken verstaan moet word nie, maar vanuit die eie aard van die nagmaal as teken self. ${ }^{28}$ Die liggaam van Christus in die nagmaal moet met ander woorde die paradigma vorm van waaruit ander opvattings van 'n teken beoordeel word, en nie andersom nie.

Hoe is dit dan nou gesteld tydens die viering van die nagmaal? As daar in terme van die drie onderskeidings ten opsigte van die liggaam van Christus gedink word (die liggaam gebore uit Maria, die sakramentele liggaam in die brood en wyn, en die kerk as liggaam), dan moet dit benadruk word dat hierdie drie "liggame van Christus" wel te onderskei is, maar dat hulle nogtans nie radikaal geskei mag word nie. Dit is eenvoudig nie moontlik of wenslik om analities te sê waar die een ophou en die ander begin nie. Op'n misterieuse wyse is elk daar in die viering van die nagmaal en gaan die een oor in die ander. So word op 'n sakramentele wyse gemanifesteer wat 'n teken is, in stede daarvan om vanuit 'n modernistiese of postmodernistiese siening van wat 'n teken is na die nagmaal te kyk. In hierdie opvatting van wat 'n teken is, is die transendente in die immanente: die Hoof is in die liggaam; die liggaam word gevorm vanuit die Hoof. Nogtans is die verhouding tussen die transendente en die immanente onkwantifiseerbaar. In hierdie verband, ten opsigte van die misterie as teken, kan die woorde van De Lubac weer genoem word: "... it should be maintained that a mystery is what continues to remain obscure, hidden and 'mystical', even once it has been described, signified and 'revealed".' Die belangrike is egter dat die absolute skeiding tussen aanwesigheid en afwesigheid oorkom word.

Die nagmaal is ' $n$ vormende gebeurtenis. Die kerk as liggaam word gevorm. Dit bring ons by die tweede opmerking: daar sal 'n herontdekking moet kom van die belang van tradisie. Reg verstaan is tradisie lewend. Dit ís juis die liggaam van Christus. Dit is nie maar bloot representasie van dieselfde in 'n volgende iterasie nie. Dit is Christus self wat oorgelewer word, en hierdie oorlewering is beliggaamd. So verstaan is die tradisie van die kerk juis iets van die transendente in die immanente van hierdie wêreld. Die kerk is die liturgiese viering en verdigting van die nuwe in die oue. Maar hierdie nuwe word juis oorgelewer van geslag tot geslag, en daarom kan daar ook nie iets anders oorgelewer word as die liggaam van Christus nie. In die woorde van Hans Boersema:

"If the church today shares, by means of a real participation, in the church's earlier

27. John Milbank \& Catherine Pickstock, Truth in Aquinas, p. 93.

28. Vgl Boersema, Heavenly Participation, Kindle plekmerker 278. 
NGTT: Oopbron - http://ngtt.journals.ac.za

tradition, that earlier tradition genuinely lives on in us and we have a sacred responsibility to it. Earlier periods of the Christian tradition and our present time are connected via a common sacramental participation in the eternal Word of God."29

Die derde opmerking het te make met die skeiding tussen plaaslike kerk en universele kerk. Hoe kan daar in die skaduwee van die altyd repeterende breuk en versnellende verbrokkeling wat die kerk sedert die aanvang van die moderne tyd aantas oor die liggaam van Christus gedink word? Hier kan nie maar bloot die weg van die minste weerstand gevolg word, waardeur verlief geneem word met die nominalistiese ontologie van ons tyd nie. Met ander woorde: dit kan nie maar so wees dat elke plaaslike kerk eintlik niks met ander kerke te doen het, behalwe tot die mate waarin daardie kerk homself pragmaties tuis voel binne'n netwerk van eendersdenkendes nie. Die kerk is juis katoliek! Dit beteken dat die andersheid van die ander een saam met die gemaklikheid van die eie in een liggaam moet wees.

Aan die anderkant lyk dit op die oomblik feitlik onmoontlik om deur middel van bestuursmatige ingrype die groter kerkstrukture, veral in reformatoriese kringe, te rehabiliteer in die rigting van'n sakramentele, deelnemende kerkwees. Hiervoor is die bestaande strukture te veel gekontamineer deur modernistiese kontraktuele denke. Wat egter wel kan gebeur, en met hierdie voorstel word die artikel afgesluit, is dat binne die kerk begin kan word met ' $n$ herontdekking van 'n sakramentele en deelnemende wêreldbeeld. Dit kan gebeur deur die herontdekking van die nagmaal as die hart van die kerk, die herontdekking van die liturgiese jaar, as 'n simbool wat deur die kerk oor die algemeen onderhou word, en gepaardgaande daarmee, die herontdekking van'n kurrikulum waarvolgens na die Woord geluister word deur die loop van die liturgiese jaar ${ }^{30}$. Die deelname aan ‘n leesrooster bind die kerk aan die groter liggaam van Christus. Vanuit ' $n$ herontdekking van hierdie lewensvorme van die kerk mag daar moontlik in die toekoms gegroei word na'n herontdekking van die waarlik sakramentele liggaam van Christus.

\section{Bibliografie}

Alliez, E. 1996. Capital Times - Tales from the Conquest of Time, trans. Georges

Van Den Abbeele. Minneapolis: University of Minnesota Press.

Ashworth, E.J. 1991. "Signification and Modes of Signifying in Thirteenth-Century

Logic: A Preface to Aquinas on Analogy" In: Medieval Philosophy and

Theology, vol. 1.

Ashworth, E.J. 2004. Medieval Theories of Analogy. In: Stanford Encyclopedia of

Philosophy. Edward N. Zalta (ed.). Available at:

http://plato.stanford.edu/entries/analogy-medieval/ (Accessed on 25-062008).

Betz, J.R. 2006. "Beyond the Sublime: The Aesthetics of the Analogy of Being (part

2)," Modern Theology, 22:1.

Bentley-Hart, D. 2003. The Beauty of the Infinite - The Aesthetics of Christian

Truth. Grand Rapids: Eerdmans.

Billings, J.T. 2010. The Word of God for the people of God - An Entryway to the

Theological Interpretation of Scripture. Grand Rapids: Eerdmans.

Boersema, H. 2011. Heavenly Participation - the weaving of a sacramental

Tapestry. Grand Rapids: Eerdmans.

De Lubac, H. 2006. Corpus Mysticum - The Eucharist and the Church in the Middle

29. Boersema, Heavenly Participation, Kindle plekmerker 1509.

30. Sien die bespreking van O'Loughlin (2012) oor die teologiese belang van die leesrooster. 
NGTT Deel 54, Nommers $1 \& 2$, Maart en Junie 2013

Ages, vert. Simmonds, G. Notre Dame, Ind.: Univ of Notre Dame Press.

Dupré, L. 1993. Passage to Modernity. New Haven: Yale University Press.

Eco, U. \& Marmo, C. (reds.) 1989. On the Medieval Theory of Signs. Amsterdam: John Benjamins Publishing Company.

Gregory, B.S. 2012. The Unintended Reformation - How a Religious Revolution Secularized Society. Cambridge, Mass.: Harvard University Press.

McCurry, J. 2007. "Towards a poetics of theological creativity: Rowan Williams reads Augustine's De Doctrina after Derrida" In: Modern Theology, 23 (3),

Milbank, J. \& Pickstock, C. 2001. Truth in Aquinas. London: Routledge

Oliver, S. "The eucharist before nature and culture" In: Modern Theology 15:3, Julie 1999. Pp. 331353.

O'Loughlin, T. Making the most of the lectionary: A user's guide. London: SPCK.

Pickstock, C. 2005. Duns Scotus: his historical and contemporary significance. Modern Theology,. 21(4).

Van Genderen, J \& Velema, W.H. 1992. Beknopte Gereformeerde Dogmatiek. Kampen: Kok.

White, T.J (red.) 2011. The Analogy of Being - Invention of the Antichrist or the Wisdom of God? Grand Rapids: Eerdmans.

\section{TREFWOORDE}

Ekklesiologie

Liturgie

Wêreldbeeld

Transendensie

Immanensie

\section{KEY WORDS}

Ecclesiology

Liturgy

Woldview

Transcendence

Immanence

\section{Contact Details/Kontakbesonderhede}

Jaco Kruger

Buitengewone Lektor, Fakulteit Teologie

Noordwes Universiteit

Suid Afrika

jaco@gkwapadrant.co.za

+27 (0) 129913339 